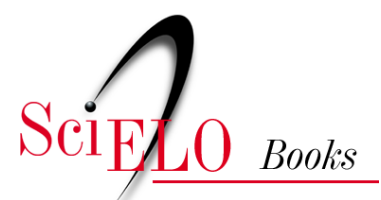

\title{
29. A Obsessão de John Hunter
}

\author{
Joffre Marcondes de Rezende
}

\section{SciELO Books / SciELO Livros / SciELO Libros}

REZENDE, J. M. A Obsessão de John Hunter. In: À sombra do plátano: crônicas de história da medicina [online]. São Paulo: Editora Unifesp, 2009, pp. 255-257. História da Medicina series, vol. 2. ISBN 978-85-61673-63-5. https://doi.org/10.7476/9788561673635.0030.

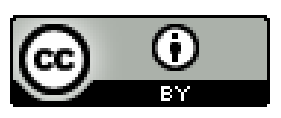

All the contents of this work, except where otherwise noted, is licensed under a Creative Commons Attribution 4.0 International license.

Todo o conteúdo deste trabalho, exceto quando houver ressalva, é publicado sob a licença Creative Commons Atribição 4.0.

Todo el contenido de esta obra, excepto donde se indique lo contrario, está bajo licencia de la licencia Creative Commons Reconocimento 4.0. 


\section{A Obsessão de John Hunter}

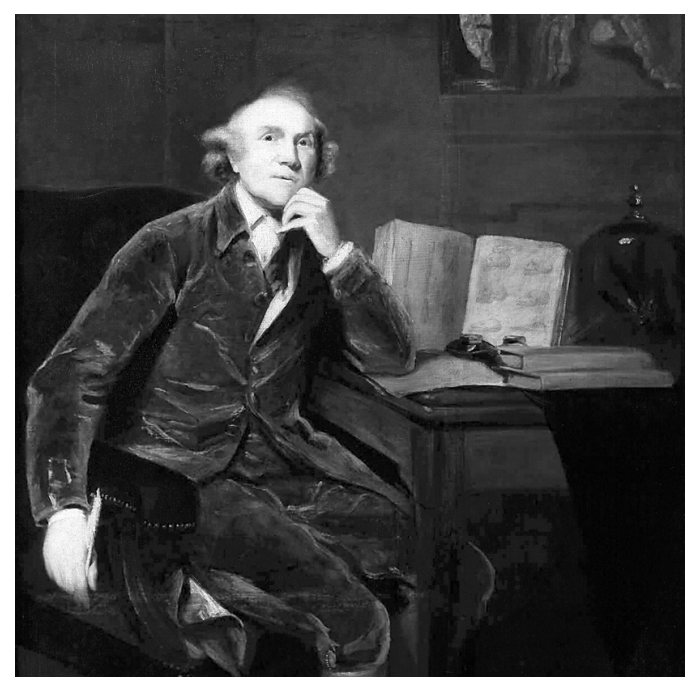

John Hunter (I728-I793).

$J$

ohn Hunter viveu na Inglaterra de I728 a I793. Era o caçula de dez irmãos, um dos quais, William Hunter, famoso anatomista e cirurgião, foi seu preceptor em anatomia. John desde cedo demonstrou grande habilidade na sala de dissecções, tendo feito algumas descobertas importantes em anatomia.

Era um trabalhador infatigável a quem bastavam quatro a cinco horas de sono e que se aborrecia com a especulação teórica, muito em voga na época, sobre doutrinas e conceitos, sem nenhuma base experimental.

Foi o fundador da cirurgia experimental e a ele se deve a descoberta da circulação colateral nos casos de aneurisma, permitindo a ligadura da artéria logo acima do saco aneurismático.

Descobriu os canais lacrimais, descreveu o choque, a flebite e a intussuscepção intestinal e foi o primeiro a utilizar a sonda nasogástrica para alimentar o paciente.

Considerava a maioria das operações como mutilações que apenas atestavam a imperfeição da medicina e advertia seus colegas cirurgiões para não 
agirem como um "selvagem armado" (Graham, I957.pp. 238-249; Major, I954, pp. 60I-606).

Estabeleceu a diferença entre o cancro mole e o cancro duro e para dirimir a dúvida se a blenorragia e a sífilis eram uma só ou duas doenças, injetou em seu próprio pênis o pus recolhido de um paciente com blenorragia. Contraiu blenorragia e apresentou todas as manifestações primárias e secundárias da sífilis, o que o convenceu de que se tratava de uma única doença. Lamentavelmente, é fora de dúvida que ele se autoinoculou com material que continha tanto o gonococo como o Treponema pallidum (Altman, I998, pp. 6-8).

Além de anatomista e cirurgião, John Hunter era um colecionador, tendo organizado em sua casa um verdadeiro museu de anatomia, patologia e história natural. Não somente coletava e preparava pessoalmente os espécimes destinados à sua coleção, como os adquiria de terceiros, gastando todas as suas economias no contínuo enriquecimento do museu, que chegou a possuir treze mil peças.

Não dispondo de espaço suficiente em sua residência, adquiriu uma pequena área nas cercanias de Londres, onde construiu a sede de seu museu e onde mantinha animais vivos para observar-lhes os hábitos e para seus estudos de cirurgia experimental (Gouthrie, I947, p. 296).

Certa vez conheceu um irlandês de grande estatura, um verdadeiro gigante, de nome Byrne e desejou possuir o esqueleto dele para o seu museu.

Ao saber das pretensões de Hunter, Byrne não somente recusou-se a fazer a doação de seu esqueleto, em caso de morte, como deixou instruções precisas para que seu corpo fosse colocado em um caixão de chumbo e jogado ao mar.

Hunter não desistiu de seu intento e a ideia de se apropriar do esqueleto de Byrne tornou-se verdadeira obsessão. Passou a acompanhar os passos de Byrne que, amedrontado, fugia sempre de encontrar-se com seu perseguidor.

O destino favoreceu a Hunter. Byrne veio a falecer e Hunter conseguiu subornar os responsáveis pelo seu sepultamento, adquirindo o corpo do gigante pela elevada soma de 500 libras esterlinas, importância que ele não possuía e teve de tomar emprestada (Major, op. cit., p. 604).

O esqueleto do gigante é hoje um dos espécimes mais famosos do Hunterian Museum, em Londres. 
Hunter faleceu aos 65 anos de idade de modo dramático. Sofria insuficiência coronariana com crises de angina do peito e chegou a prever o seu fim com as seguintes palavras: "minha vida está nas mãos de qualquer canalha que queira me aborrecer e contrariar". Em uma reunião da diretoria do Hospital St. George em que se discutia quem seria o seu sucessor no Hospital, teve uma discussão acalorada com seus interlocutores e caiu fulminado por um infarto agudo do miocárdio (Idem, p. 605).

\section{Referências Bibliográficas}

Altman, L. K. The Story of Self Experimentation in Medicine. Berkeley, University of California Press, I998.

Graham, H. Surgeons all. New York, Philosophical Library, I957.

Guthrie, D. Historia de la Medicina. Barcelona, Salvat Editores, I 947.

Major, R. H. A History of Medicine. Oxford, Blackwell Scientific Publications, I954. 
